\title{
Harmful Chemicals in Soil and Risk Assessment of an Abandoned Open Dumpsite in Eastern China
}

\author{
Ying Huang, YongXia Li, Jian Yang, MinMin Xu, Bo Sun, FuWei Gao, and Ning Wang \\ Institute of Ecology and Soil Remediation, Shandong Academy of Environmental Science, Jinan 250013, China \\ Correspondence should be addressed to Ying Huang; sdhy07@hotmail.com
}

Received 20 August 2014; Accepted 11 September 2014

Academic Editor: Jian Lu

Copyright (C) 2015 Ying Huang et al. This is an open access article distributed under the Creative Commons Attribution License, which permits unrestricted use, distribution, and reproduction in any medium, provided the original work is properly cited.

\begin{abstract}
The concentrations of pollutants in soil samples collected in and around a dumpsite in Heze, Shandong, China, were investigated, and the potential ecological and health risks of these pollutants were assessed. Seventeen soil samples from five different locations were analysed for pollution characteristics, and the target pollutants included inorganic pollutants and heavy metals as well as volatile organic compounds/semivolatile organic compounds (VOCs/SVOCs). Results showed that the mean concentration level of each pollutant from the interior area was relatively higher than that from the boundary area of the dumpsite. Inorganic pollutants and heavy metals were detected in all of the soil samples. According to potential ecological risk assessment with environmental background values of Shandong as screening values, heavy metals in majority of the samples pose low ecological risk to the ecosystem except $\mathrm{Hg}$. $\mathrm{Hg}$ poses a considerable or very high risk because of its high levels of accumulation. In consideration of future land use pattern, human health risks derived from environmental exposure to heavy metals were assessed. Carcinogenic risk and noncarcinogenic hazards for adults are acceptable, while noncarcinogenic hazards for children exceed the safety threshold. The health risks are primarily attributed to oral exposure to As and Cr.
\end{abstract}

\section{Introduction}

Solid wastes are disposed of either in open dumps or sanitary landfills or by incineration worldwide [1]. In many developing countries, large amounts of municipal solid wastes (MSW) are dumped into open dumping sites each day without adequate management. This practice causes several adverse environmental consequences and increases health risks to local communities [2]. China generates approximately 370 million tons of MSW per year, of which 190 million tons comes from rural areas [3]. Suburbs in China frequently use open dumps, which are the most common type of nonengineered disposal where MSW are simply dumped into natural pits or hollows [4-6]. No liner systems, gas controls, leachate controls, or leachate treatments are used in this type of waste disposal site [7]. Although China has issued a series of laws and regulations on waste disposal, including the siting and operation of landfills, the existing issue regarding open dumpsites remains a difficult problem to solve.
Landfill leachate is highly concentrated refractory organic wastewater containing complex components, including ammonia, organics, heavy metals, and certain toxic substances $[8,9]$. More than 200 organic compounds have been identified in municipal landfill leachate, with more than 35 compounds having the potential to harm the environment and human health [10]. As a result of leachate migration, soils have been contaminated with heavy metals such as $\mathrm{Pb}, \mathrm{Cu}$, $\mathrm{Zn}, \mathrm{Fe}, \mathrm{Mg}, \mathrm{Cr}$, and $\mathrm{Cd}$; these heavy metals in solid wastes are not biodegradable and therefore cause serious problems [11]. Heavy metal concentrations in the soil sample collected from the MSW open dumpsite in Tamil Nadu were found in the following order: $\mathrm{Mn}>\mathrm{Pb}>\mathrm{Cu}>\mathrm{Cd}$ [12]. Soils at the disposal sites showed high $\mathrm{pH}$ and total dissolved solids (TDS) and electrical conductivity (EC) regimes. Soils at the disposal sites showed high $\mathrm{pH}$ and TDS and EC regime in comparison to control sites. Various heavy metal concentrations $(\mathrm{Pb}, \mathrm{Cu}, \mathrm{Ni}$, $\mathrm{Cr}$, and $\mathrm{Zn}$ ) were also found to be higher at dumping sites except for Cd which had a higher value in control site [13]. 


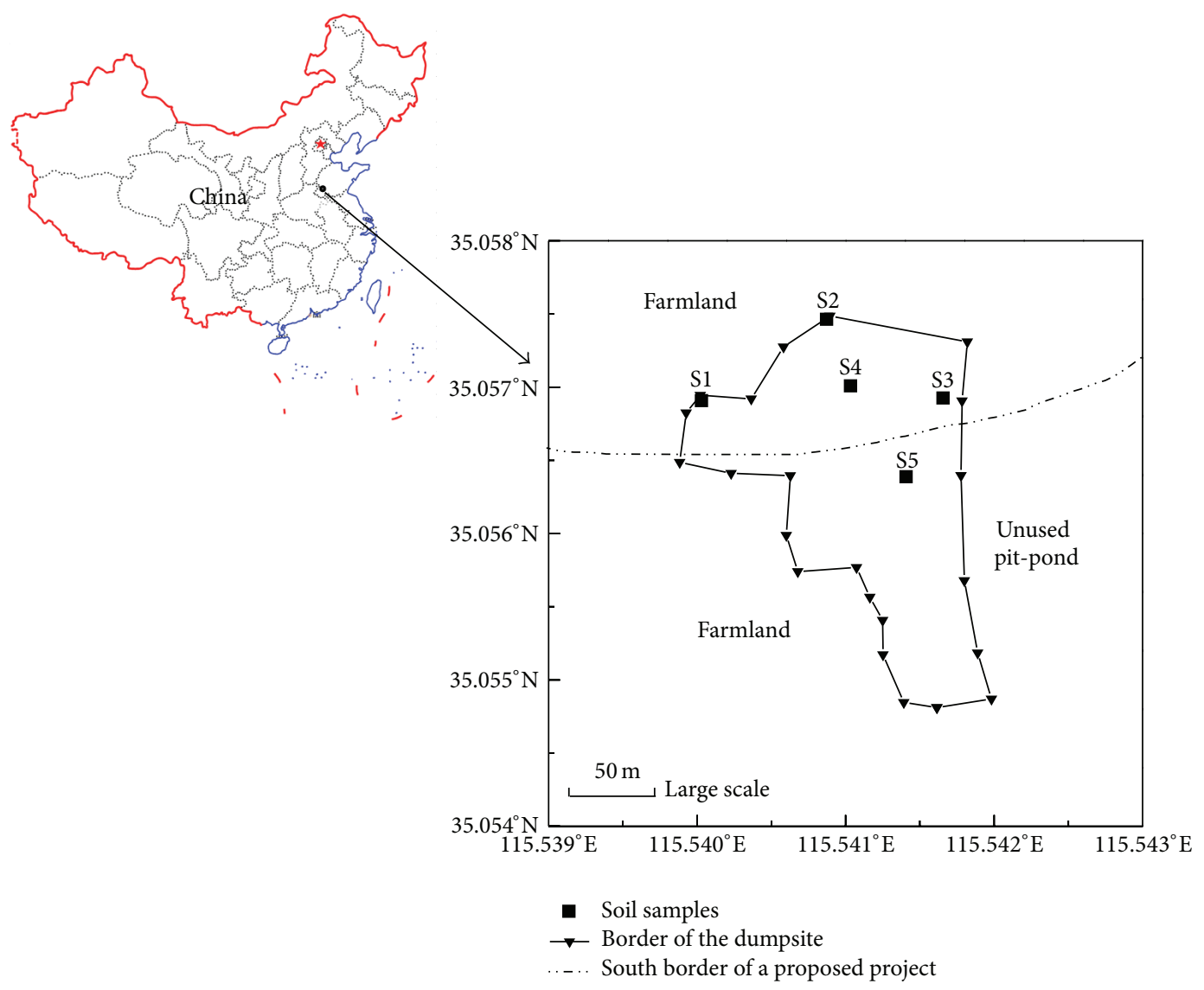

FIGURE 1: Range of the open dumpsite and locations of soil sampling in the study area.

The average heavy metal content in the similar rural waste followed the sequence of $\mathrm{Zn}>\mathrm{Cu}>\mathrm{Cr}>\mathrm{Pb}>\mathrm{Cd}$ [14]. As a medium on which MSW are deposited, soil is a natural resource that needs to be carefully monitored before, during, and after dumpsite activity.

This study examines random samples obtained from an abandoned open dumpsite in the suburbs in Heze, Shandong, China. A total of 17 soil samples from five different locations were quantitatively analyzed for 15 inorganic pollutants and heavy metals and 195 volatile organic compounds/semivolatile organic compounds (VOCs/SVOCs). In addition, the species and distribution characteristics of the pollutants were determined. The potential ecological and human health risks of pollutants exceeding the screening levels were assessed. This study provides a reference for soil risk management in this region and offers a guide for future soil disposal and land use patterns.

\section{Materials and Methods}

2.1. Site Description. The inner suburbs located on the Huai River basin of the Yellow River alluvial plain lie at the southeast of Heze, Shandong, China $\left(115^{\circ} 29^{\prime} \mathrm{E}\right.$ to $115^{\circ} 40^{\prime} \mathrm{E}$, $34^{\circ} 57^{\prime} \mathrm{N}$ to $35^{\circ} 14^{\prime} \mathrm{N}$ ). The terrain slopes from south to north. Preliminary investigations indicated that the soil components of the site are miscellaneous fill in the upper $400 \mathrm{~cm}$, sandy and clay loam at $401 \mathrm{~cm}$ to $1000 \mathrm{~cm}$, silt clay at $1000 \mathrm{~cm}$ to $1200 \mathrm{~cm}$, and sandy loam at $1200 \mathrm{~cm}$ and below. The groundwater is commonly hosted in the Quaternary aquifer, and the flow is from west to east.

The open dumpsite was originally an abandoned kiln pit site. The site was in operation from 1995 to 2011, and it covered an area of approximately $3.0 \mathrm{hm}^{2}$. Approximately $150,000 \mathrm{~m}^{3}$ of MSW was deposited, covering the entire pit five meters deep. After the dumpsite is decommissioned, the land would be used for infrastructure construction. According to an onsite inspection, the border of the site was positioned with a handheld GPS, as shown in Figure 1.

2.2. Sample Collection and Analysis. In consideration of the defined future land use patterns and scale, 17 soil samples were obtained from the dumpsite in November 2012 (Figure 1). Samples from the border area were gathered with the use of a vehicle-mounted soil core sampler (model 6620 DT, Geoprobe, Salina, KS). Thirteen soil samples were acquired from the unit where soil texture changed or pollution signs were found. For soil samples in the interior area, where the Geoprobe system could not work, an excavator was used for cross-section and four soil samples were acquired. The specific sampling depths are shown in Table 1.

Inorganic pollutants were determined using an atomic absorption spectrometer (AAS) (Perkin-Elmer, Norwalk, 
TABLE 1: Soil sampling depths at the abandoned open dumpsite.

\begin{tabular}{|c|c|c|c|c|c|}
\hline \multirow{2}{*}{ Points } & \multicolumn{3}{|c|}{ Points from boundary area of the site } & \multicolumn{2}{|c|}{ Points from interior area of the site } \\
\hline & S1 & $\mathrm{S} 2$ & S3 & $\mathrm{S} 4$ & S5 \\
\hline Sampling depth/m & 2.0/5.0/8.0/9.6 & 2.0/5.0/8.0/11.0/15.0 & 1.0/4.0/7.0/10.6 & $0.5 / 1.9$ & $1.0 / 2.0$ \\
\hline
\end{tabular}

$\mathrm{CT})$. Concentrations of $\mathrm{Cr}, \mathrm{As}, \mathrm{Pb}$, and $\mathrm{Hg}$ were measured using an XSERIES 2 inductively coupled plasma mass spectrometer (ICP-MS) (Thermo Scientific, MA) and concentrations of $\mathrm{Cu}, \mathrm{Zn}$, and $\mathrm{Ni}$ were analyzed using inductively coupled plasma optical emission spectrometry (ICP-OES) (Agilent Technologies, Santa Clara, CA). Concentrations of VOCs/SVOCs were analysed using a gas mass chromatography (GC-MS) following the standard method of US EPA.

2.3. Potential Ecological Risk Assessment Model. The potential ecological risk index (RI) was introduced by Hakanson [15], according to the toxicity of elements and the response of the environment, to assess the degree of elements pollution in sediments [16]:

$$
\begin{gathered}
C_{f}^{i}=\frac{C^{i}}{C_{n}^{i}}, \\
E_{r}^{i}=T_{r}^{i} \times C_{f}^{i}, \\
\mathrm{RI}=\sum E_{r}^{i},
\end{gathered}
$$

where RI is the sum of all of the risk factors for elements in the soils, $E_{r}^{i}$ is the monomial ecological risk factor, $C^{i}$ represents the concentration of elements in the soils, $C_{n}^{i}$ is the regional background value of elements, $C_{f}^{i}$ is the pollution coefficient, and $T_{r}^{i}$ is the toxic-response factor for a given substance, which accounts for the toxic and sensitivity requirements. On the basis of the approach proposed by Chen et al., the toxicresponse factors for $\mathrm{As}, \mathrm{Cr}, \mathrm{Cu}, \mathrm{Pb}, \mathrm{Ni}, \mathrm{Zn}$, and $\mathrm{Hg}$ are 10,2 , $5,5,5,1$, and 40 , respectively [17]. Five pollution categories of $E_{r}^{i}$ and four pollution categories of RI are recognised on the basis of the ecological risks [15].

\subsection{Human Health Risk Assessment Model}

2.4.1. Exposure Model. Referring to health risk assessment guidelines [18, 19], procedure of health risk assessment generally includes four steps: risk identification, exposure analysis, toxicity evaluation, and risk assessment. Pollutants in the soil enter the body via three main pathways [20]: (a) direct ingestion of substrate particles $\left(D_{\text {ing-s }}\right)$, (b) inhalation of suspended particles through the mouth and nose $\left(D_{\text {inh-s }}\right)$, and (c) dermal absorption of elements in particles adhered to exposed skin $\left(D_{\text {der-s }}\right)$. When conducting exposure analysis, a specific approach characteristic for human exposure to soil in the sites is applied, taking particular care of the noncarcinogenic hazard exposure for children. For noncarcinogenic hazards, the elemental dose $\left(D, \mathrm{mg} \cdot \mathrm{kg}^{-1} \cdot \mathrm{d}^{-1}\right)$ received by children or adults through each of these pathways was recalculated by using

$$
\begin{aligned}
& \text { oral dose }\left(D_{\text {ing-s }}\right) \text { : } \\
& \qquad D_{\text {ing-s }}=\frac{C_{S} \times \operatorname{IngR} \times \mathrm{EF} \times \mathrm{ED} \times \mathrm{CF}}{\mathrm{BW} \times \mathrm{AT}} ;
\end{aligned}
$$

inhalation dose $\left(D_{\text {inh-s }}\right)$ :

$$
D_{\text {inh-s }}=C_{S} \times \frac{\mathrm{InhR} \times \mathrm{EF} \times \mathrm{ED}}{\mathrm{BW} \times \mathrm{AT} \times \mathrm{PEF}}
$$

dermal dose $\left(D_{\text {der-s }}\right)$ :

$$
D_{\text {der-s }}=\frac{C_{S} \times \mathrm{SA} \times \mathrm{SL} \times \mathrm{ABS} \times \mathrm{EF} \times \mathrm{ED} \times \mathrm{CF}}{\mathrm{BW} \times \mathrm{AT}},
$$

where $C_{S}$ is the concentration of the pollutant in the soil from the exposure point $\left(\mathrm{mg} \cdot \mathrm{kg}^{-1}\right)$, IngR is the soil ingestion rate for the receptor $\left(\mathrm{mg} \cdot \mathrm{d}^{-1}\right)$, InhR is the soil inhalation rate for the receptor $\left(\mathrm{m}^{3} \cdot \mathrm{d}^{-1}\right), \mathrm{EF}$ is the exposure frequency (days.year ${ }^{-1}$ ), ED is exposure duration (years), PEF is soil-toair particulate emission factor $\left(\mathrm{m}^{3} \cdot \mathrm{kg}^{-1}\right), \mathrm{SA}$ is skin surface area available for exposure $\left(\mathrm{cm}^{2}\right)$, SL is soil-to-skin adherence factor $\left(\mathrm{mg} \cdot \mathrm{cm}^{-2} \cdot\right.$ event $\left.^{-1}\right)$, ABS is dermal absorption factor (dimensionless), BW is time-averaged body weight $(\mathrm{kg})$, and AT is average time of noncarcinogenic and carcinogenic risks (days). Exposure scenarios were modified as appropriate to reflect conditions unique to the actual conditions in China (Table 2).

Carcinogenic risk is calculated for lifetime exposure and is estimated as the incremental probability of an individual to develop cancer over a lifetime as a result of total exposure to potential carcinogens [21]. The corresponding daily exposure dose (LADD) is calculated according to the following equation:

$$
\begin{aligned}
\mathrm{LADD}= & \frac{C \times \mathrm{EF}}{\mathrm{AT}} \\
& \times\left(\frac{\mathrm{CR}_{\text {child }} \times \mathrm{ED}_{\text {child }}}{\mathrm{BW}_{\text {child }}}+\frac{\mathrm{CR}_{\text {adult }} \times \mathrm{ED}_{\text {adult }}}{\mathrm{BW}_{\text {adult }}}\right),
\end{aligned}
$$

where LADD is the sum of average exposure dose via multiple pathways per lifecycle $(\mathrm{mg} \cdot \mathrm{kg} \cdot \mathrm{d})^{-1}$, AT is the average exposure time $(\mathrm{d})$, AT is life expectancy $\times 365$, and CR is intake intensity (oral ingestion and inhalation pathways, $\mathrm{CR}$ = IngR and CR = InhR, resp.; for dermal contact pathway, $\mathrm{CR}$ $=\mathrm{SA} \cdot \mathrm{SL} \cdot \mathrm{ABS})$.

2.4.2. Risk Characterization. The $D$ for each element and exposure pathway was subsequently divided by the corresponding reference dose to yield a hazard quotient (HQ) for systemic toxicity [18]. The cumulative noncarcinogenic hazard is expressed as the hazard index (HI) (see (6)):

$$
\mathrm{HI}=\sum_{i=1}^{m} \sum_{j=1}^{n} \mathrm{HQ}_{i j}=\sum_{i=1}^{m} \sum_{j=1}^{n}\left(\frac{D}{\mathrm{RfD}}\right)_{i j},
$$


TABLE 2: Variables used to assess human exposure to the soil.

\begin{tabular}{|c|c|c|}
\hline \multirow{2}{*}{ Parameters } & \multicolumn{2}{|c|}{ Reference value } \\
\hline & Adults & Children \\
\hline IngR/mg. $\mathrm{d}^{-1}$ & 100 & 200 \\
\hline $\operatorname{InhR} / \mathrm{m}^{3} \cdot \mathrm{d}^{-1}$ & 12.80 & 7.63 \\
\hline $\mathrm{EF} / \mathrm{d}$ & 350 & 320 \\
\hline $\mathrm{ED} / \mathrm{yrs}$ & 24 & 6 \\
\hline $\mathrm{BW} / \mathrm{kg}$ & 56.8 & 15.9 \\
\hline \multirow{2}{*}{ AT/d } & $24 \times 365=8,760$ & $6 \times 365=2,190$ \\
\hline & \multicolumn{2}{|c|}{ For carcinogenic risk, $\mathrm{AT}=72 \times 365=26,280$} \\
\hline $\mathrm{SA} / \mathrm{cm}^{2}$ & 2,145 & 1,150 \\
\hline $\mathrm{SL} / \mathrm{mg} \cdot \mathrm{cm}^{-2}$ & 0.07 & 0.20 \\
\hline $\mathrm{ABS} /-$ & \multicolumn{2}{|c|}{ For As, $\mathrm{ABS}=0.03$; for other heavy metals, $\mathrm{ABS}=0.001$} \\
\hline $\mathrm{PEF} / \mathrm{m}^{3} \cdot \mathrm{kg}^{-1}$ & \multicolumn{2}{|c|}{$1.36 E+09$} \\
\hline
\end{tabular}

TABLE 3: Reference doses (RfD) for noncarcinogens and slope factors (SF) for carcinogens [20, 33, 34].

\begin{tabular}{|c|c|c|c|c|c|c|}
\hline \multirow{2}{*}{ Heavy metals } & \multicolumn{3}{|c|}{$\mathrm{RfD} / \mathrm{mg} \cdot \mathrm{kg}^{-1} \cdot \mathrm{d}^{-1}$} & \multicolumn{3}{|c|}{$\mathrm{SF} / \mathrm{kg} \cdot \mathrm{d} \cdot \mathrm{mg}^{-1}$} \\
\hline & $\mathrm{RfD}_{\text {ing }}$ & $\mathrm{RfD}_{\text {inh }}$ & $\mathrm{RfD}_{\text {dermal }}$ & $\mathrm{SF}_{\text {ing }}$ & $\mathrm{SF}_{\mathrm{inh}}$ & $\mathrm{SF}_{\text {dermal }}$ \\
\hline As & $3.00 E-04$ & & $1.23 E-04$ & $1.50 E+00$ & $1.51 E+00$ & $3.66 E+00$ \\
\hline $\mathrm{Cr}$ & $3.00 E-03$ & $2.86 E-05$ & $6.00 E-05$ & & $4.2 E+01$ & \\
\hline $\mathrm{Cu}$ & $4.00 E-02$ & $4.02 E-02$ & $1.20 E-02$ & & & \\
\hline $\mathrm{Pb}$ & $1.40 E-03$ & $3.52 E-03$ & $5.25 E-05$ & $8.50 E-03$ & & \\
\hline $\mathrm{Ni}$ & $2.00 E-02$ & $2.06 E-02$ & $5.40 E-03$ & & $8.40 E-1$ & \\
\hline $\mathrm{Zn}$ & $3.00 E-01$ & $3.00 E-01$ & $6.00 E-02$ & & & \\
\hline $\mathrm{Hg}$ & $3.00 E-04$ & $8.57 E-05$ & $3.00 E-05$ & & & \\
\hline
\end{tabular}

where $m$ and $n$ represent pollutant type and number of exposure pathways, respectively.

For carcinogens, the dose was multiplied by the corresponding slope factor (SF) to produce a level of excess lifetime cancer risk (see Table 3 ). The cumulative carcinogenic risk was expressed as the total cancer risk $\left(R_{\text {Total }}\right)$ (see (7)):

$$
R_{\mathrm{Total}}=\sum_{i=1}^{m} \sum_{j=1}^{n} R_{i j}=\sum_{i=1}^{m} \sum_{j=1}^{n}(\mathrm{LADD} \cdot \mathrm{SF})_{i j} .
$$

Risk characterization was considered separately for carcinogenic and noncarcinogenic effects. Health risk was obtained by comparing the calculated HI and $R_{\text {Total }}$ values with the recommended maximum values. If the HI value is less than one, the exposed population is unlikely to experience obvious adverse health effects. If the HI value exceeds one, then adverse health effects may occur [22]. $R_{\text {Total }}$ surpassing $1 E-04$ are viewed as unacceptable, $R_{\text {Total }}$ below $1 E-06$ are not considered to pose significant health risks, and $R_{\text {Total }}$ lying between $1 E-04$ and $1 E-06$ are generally considered acceptable, depending on the situation and circumstances of exposure [23].

\section{Results and Analysis}

3.1. Inorganic Pollutants and Heavy Metals in Soils. The concentrations of inorganic pollutants and heavy metals in soil samples were detected along the depth of the soil layer at the site; the results are shown in Table 4 . The detection rates for total cyanide and $\mathrm{Hg}$ were $5.9 \%$ and $23.5 \%$, respectively; six kinds of heavy metals ( $\mathrm{Sb}, \mathrm{Cd}, \mathrm{Be}, \mathrm{Se}, \mathrm{Ag}$, and $\mathrm{Tl}$ ) were not detected. Total fluorine had the highest level because of the high background value of fluorine ion in the local shallow groundwater [24]. The heavy metal concentration in the soil sample was found in the following order: $\mathrm{Zn}>\mathrm{Cr}>\mathrm{Ni}>\mathrm{Cu}>$ $\mathrm{Pb}>\mathrm{As}>\mathrm{Hg}$. The highest levels of total cyanide, $\mathrm{Cr}, \mathrm{Cu}, \mathrm{Pb}$, $\mathrm{Zn}$, and $\mathrm{Hg}$, were found in the topsoil of the site (Points S4, S5). Compared with the environmental background values for Shandong, $100 \%$ of As, $58.8 \%$ of Cr, $52.9 \%$ of Cu, $64.7 \%$ of $\mathrm{Ni}$, and $58.8 \%$ of $\mathrm{Zn}$ exceeded the corresponding values, with exceeding ratios of $1.03,0.01,0.14,0.14$, and 0.42 , respectively. The average concentration of total fluorine and $\mathrm{Pb}$ did not exceed the background values, whereas $35.3 \%$ of total fluorine and $11.8 \%$ of $\mathrm{Pb}$ exceeded the corresponding values.

In the United States and a number of European countries, trigger values or soil quality criteria for more common contaminants are used as screening levels during contaminated land risk assessment [25]. When the second standard of GB15618-1995 is used for the screening, $\mathrm{Zn}$ (topsoil of Point S4) exceeds the standard with the ratio of 0.6 , and the other elements generally do not exceed the levels. When land is categorised under residential land use pattern according to China DB11/T-2011, As exceeds the level along the various depths of the soil layer, with $35.3 \%$ of As exceeding the value. When regional screening levels (RSLs) are used with land falling under the residential land use pattern, As exceeds 
TABle 4: Pollution status of inorganic pollutants and heavy metals at the open dumpsite.

\begin{tabular}{|c|c|c|c|c|c|c|c|c|c|c|}
\hline \multicolumn{2}{|c|}{ Sample code } & \multicolumn{9}{|c|}{ Concentration of inorganic pollutants and heavy metals $/ \mathrm{mg} \cdot \mathrm{kg}^{-1}$} \\
\hline Points & Depth $(\mathrm{m})$ & Total fluoride & Total cyanide & As & $\mathrm{Cr}$ & $\mathrm{Cu}$ & $\mathrm{Pb}$ & $\mathrm{Ni}$ & $\mathrm{Zn}$ & $\mathrm{Hg}$ \\
\hline \multirow{4}{*}{ S1 } & 2.0 & 266 & ND & 15.2 & 44.4 & 12.9 & 12.8 & 20.3 & 48.2 & ND \\
\hline & 5.0 & 539 & ND & 20.5 & 71.4 & 31.5 & 19.4 & 41.2 & 86.0 & ND \\
\hline & 8.0 & 262 & ND & 13.2 & 44.5 & 10.6 & 11.5 & 18.3 & 39.3 & ND \\
\hline & 9.6 & 479 & ND & 15.9 & 66.8 & 28.4 & 19.1 & 34.7 & 79.3 & 0.05 \\
\hline \multirow{5}{*}{ S2 } & 2.0 & 297 & ND & 14.3 & 42.6 & 12.5 & 10.5 & 20.0 & 41.9 & ND \\
\hline & 5.0 & 560 & ND & 24.2 & 76.2 & 31.7 & 19.7 & 42.2 & 87.0 & ND \\
\hline & 8.0 & 305 & ND & 12.5 & 46.0 & 12.2 & 12.5 & 20.3 & 41.8 & ND \\
\hline & 11.0 & 531 & ND & 22.2 & 74.3 & 31.6 & 19.4 & 39.0 & 85.9 & ND \\
\hline & 15.0 & 386 & ND & 15.7 & 46.2 & 14.5 & 13.6 & 23.4 & 50.3 & ND \\
\hline \multirow{4}{*}{ S3 } & 1.0 & 439 & ND & 18.8 & 68.0 & 21.6 & 14.7 & 31.4 & 66.3 & ND \\
\hline & 4.0 & 610 & ND & 21.0 & 72.3 & 27.9 & 19.1 & 36.6 & 79.8 & ND \\
\hline & 7.0 & 286 & ND & 17.9 & 48.2 & 11.5 & 10.8 & 19.6 & 42.5 & ND \\
\hline & 10.6 & 505 & ND & 20.3 & 75.3 & 33.9 & 21.4 & 41.2 & 91.7 & ND \\
\hline \multirow{2}{*}{ S4 } & 0.5 & 256 & 1.1 & 12.1 & 115.0 & 45.7 & 41.5 & 28.9 & 399.0 & 0.12 \\
\hline & 1.9 & 284 & ND & 17.9 & 43.6 & 11.8 & 11.1 & 20.6 & 43.4 & ND \\
\hline \multirow{2}{*}{ S5 } & 1.0 & 238 & ND & 14.9 & 116.0 & 53.0 & 44.0 & 37.2 & 130.0 & 0.43 \\
\hline & 2.0 & 537 & ND & 23.8 & 73.0 & 30.5 & 18.1 & 40.1 & 84.2 & 0.05 \\
\hline Averag & & 398.82 & & 17.67 & 66.11 & 24.81 & 18.78 & 30.29 & 88.04 & \\
\hline Environmental backgroun & values of Shandong & 499 & NA & 8.7 & 65.2 & 21.7 & 24.3 & 23 & 61.9 & 0.016 \\
\hline \multirow{4}{*}{ Soil environmental criteria } & China $^{\mathrm{a}}$ & NA & NA & 30 & 200 & 100 & 300 & 50 & 250 & 0.5 \\
\hline & Beijing ${ }^{\mathrm{b}}$, China & 650 & 300 & 20 & 250 & 600 & 400 & 50 & 3500 & 10 \\
\hline & USEPA $^{c}$ & 3100 & 1600 & 0.39 & NA & 3100 & 400 & 3700 & 23000 & 10 \\
\hline & USEPA $^{\mathrm{d}}$ & NA & NA & 18 & NA & 70 & 120 & 38 & 160 & NA \\
\hline
\end{tabular}

${ }^{\mathrm{a}}$ Secondary standard of environmental quality standard for soils (China, $6.5<\mathrm{pH}<7.5$ ); ${ }^{\mathrm{b}}$ screening values for environmental risk assessment of sites under residential land use pattern (Beijing, China); ${ }^{c}$ RSLs under residential land use pattern (USEPA); ${ }^{\mathrm{d}}$ Eco-SSLs (higher plants as protected objects). ND: some pollutants are not detected. NA: some pollutants are nonexistent in one standard.

the level in each layer of every point, at exceeding ratios ranging from 31.05 to 61.05 . When ecological soil screening levels (Eco-SSLs) are used (with higher plants as protected objects), $41.2 \%$ of As, $29.4 \%$ of $\mathrm{Ni}$, and $5.9 \%$ of $\mathrm{Zn}$ exceed the levels along the various soil layers. For screening purposes, further risk assessment of heavy metals must be performed by combining specific assessment models [26].

3.2. VOCs/SVOCs in Soils. VOCs/SVOCs concentrations in the soil samples were detected along the soil layer depths at the site; the results are shown in Table 5. VOCs/SVOCs were detected only in the topsoil of S4 and S5 among the 17 soil samples, and only 11 kinds of VOCs/SVOCs were detectable in 17 categories, for a total of 195 VOCs/SVOCs. DEHP, 3,4methylphenol and phenol were detectable in both points, indicating that the topsoil in the interior area of the site had been leaching poison, with a limited influence depth of less than $2 \mathrm{~m}$ for organic pollution.

The second standard, China GB15618-1995, and Eco-SSLs have no related provisions regarding VOCs/SVOCs. When the screening levels are based on China DB11/T-2011 and RSLs, all of the concentrations of VOCs/SVOCs are below the corresponding levels. Therefore, the soils in the site are only slightly contaminated by VOCs/SVOCs, and no further risk assessment is needed.
3.3. Potential Ecological Risk Assessment of Heavy Metals in Soils. According to various reference systems, large differences of $E_{r}^{i}$ may occur among the results. The environmental background values of Shandong and the secondary standard referred to in GB15618-1995 are considered as screening levels. The potential ecological risk indices $\left(E_{r}^{i}, \mathrm{RI}\right)$ of heavy metals are shown in Table 6.

With the use of environmental background values of Shandong as screening levels, $E_{r}^{i}$ for heavy metals detected is less than 40, except for Hg. Therefore, the above-mentioned heavy metals pose low ecological risk to the ecosystem. The ecological risk of $\mathrm{Hg}$ content ranges from very high to extremely strong with $E_{r}^{i}$, that is, from 125 to $1,075 . E_{r}^{i}$ for $\mathrm{Hg}$ under reporting threshold is 62.5 with medium ecological risk when the concentration of $\mathrm{Hg}$ is calculated as half of the threshold. As the reporting threshold of $\mathrm{Hg}$ is higher than the background value, the data of $E_{r}^{i}$ may overestimate the risk of $\mathrm{Hg}$ and the combined risks of soil samples. Comparison of the values of RI among different heavy metals reveals that the ecological risk of individual heavy metals (except As) in the soil from the interior area of the site is higher than that from the boundary area. The combined ecological risk of the soil samples from the boundary area is mainly in low level, lower than that from the interior area, which poses considerable to very high risk to the ecosystem. In using the secondary 


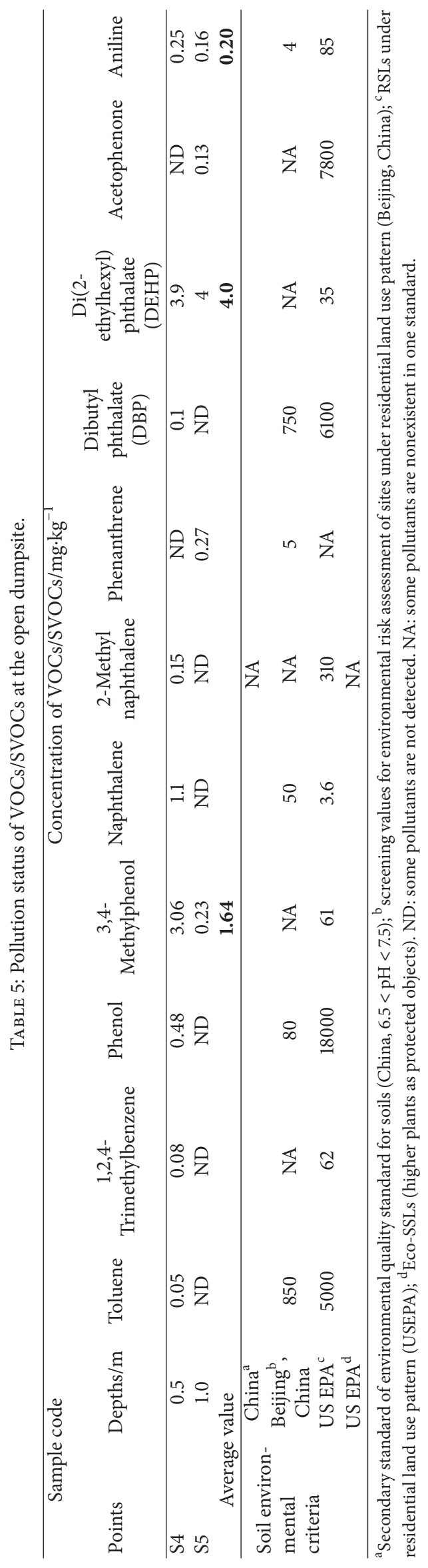


TABLE 6: Potential ecological risk indices $\left(E_{r}^{i}, \mathrm{RI}\right)$ of heavy metals in the soils.

\begin{tabular}{|c|c|c|c|c|c|c|c|c|c|c|}
\hline & \multirow{2}{*}{ Reference value } & & \multicolumn{7}{|c|}{ Potential ecological risk index $\left(E_{r}^{i}\right)$} & \multirow{2}{*}{ RI } \\
\hline & & & As & $\mathrm{Cr}$ & $\mathrm{Cu}$ & $\mathrm{Pb}$ & $\mathrm{Ni}$ & $\mathrm{Zn}$ & $\mathrm{Hg}$ & \\
\hline \multirow{6}{*}{$\begin{array}{l}\text { Soil in the interior } \\
\text { area of the } \\
\text { dumpsite }\end{array}$} & \multirow{3}{*}{$\begin{array}{l}\text { Environmental } \\
\text { background values } \\
\text { of Shandong }\end{array}$} & Maximum & 27.36 & 3.56 & 12.21 & 9.05 & 8.72 & 6.45 & 1075.00 & 1127.14 \\
\hline & & Minimum & 13.91 & 1.34 & 2.72 & 2.28 & 4.48 & 0.70 & $62.50^{*}$ & $94.59^{*}$ \\
\hline & & Average & 19.74 & 2.67 & 8.12 & 5.90 & 6.89 & 2.65 & $390.63^{*}$ & $494.69^{*}$ \\
\hline & \multirow{3}{*}{ China $^{a}$} & Maximum & 7.93 & 1.16 & 2.65 & 0.73 & 4.01 & 1.60 & 34.40 & 48.15 \\
\hline & & Minimum & 4.03 & 0.44 & 0.59 & 0.19 & 2.06 & 0.17 & $2.00^{*}$ & $11.41^{*}$ \\
\hline & & Average & 5.73 & 0.87 & 1.76 & 0.48 & 3.17 & 0.66 & $12.50^{*}$ & $29.76^{*}$ \\
\hline \multirow{6}{*}{$\begin{array}{l}\text { Soil in the } \\
\text { boundary area of } \\
\text { the dumpsite }\end{array}$} & \multirow{4}{*}{$\begin{array}{l}\text { Environmental } \\
\text { background values } \\
\text { of Shandong }\end{array}$} & Maximum & 27.82 & 2.34 & 7.81 & 4.40 & 9.17 & 1.48 & 125.00 & 164.62 \\
\hline & & Minimum & 14.37 & 1.31 & 2.44 & 2.16 & 3.98 & 0.63 & $62.50^{*}$ & $88.46^{*}$ \\
\hline & & Average & 20.49 & 1.83 & 4.98 & 3.24 & 6.49 & 1.04 & $67.31^{*}$ & $105.37^{*}$ \\
\hline & & Maximum & 8.07 & 0.76 & 1.70 & 0.36 & 4.22 & 0.37 & 4.00 & $17.31^{*}$ \\
\hline & \multirow[t]{2}{*}{ China $^{a}$} & Minimum & 4.17 & 0.43 & 0.53 & 0.18 & 1.83 & 0.16 & $2.00^{*}$ & $9.55^{*}$ \\
\hline & & Average & 5.94 & 0.60 & 1.08 & 0.26 & 2.99 & 0.26 & $2.15^{*}$ & $13.30^{*}$ \\
\hline
\end{tabular}

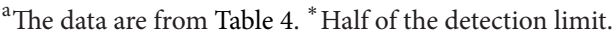

standard referred to in GB15618-1995 as a screening level, the ecological risk of detectable individual heavy metal is low in general, and the results show that the soil samples from all the points have low ecological risks.

The differences in potential ecological risk exist between the soils samples from the interior and boundary areas of the site; however, the potential ecological risks of these samples are generally low under the two reference systems. Hg should be a concern because of its high potential ecological risk based on the environmental background values of Shandong. The Hg concentration detected is lower than the secondary standard of GB15618-1995, which aims to protect agricultural productions and sustain human health. $\mathrm{Hg}$ is generally considered to come from discarded batteries (e.g., alkaline batteries), electrical appliances, newspapers, magazines, and thermometer [27]. Therefore, a system for sorting rubbish can effectively prevent $\mathrm{Hg}$ accumulation in soil.

3.4. Human Health Risk Assessment of Heavy Metals in Soils. Up to $95 \%$ UCL of the arithmetic mean concentration of each pollutant is considered when calculating the value of the health risks. However, such method tends to overestimate the level of risks [28]. Thus, this study combines the overall pollution characteristics of the soil in the site and uses the mean concentration of heavy metals in soil from the interior and boundary areas.

3.4.1. Noncarcinogenic Hazards. Table 7 presents the noncarcinogenic hazard values for the oral $\left(\mathrm{HQ}_{\text {ing }}\right)$, inhalation $\left(\mathrm{HQ}_{\mathrm{inh}}\right)$, and dermal $\left(\mathrm{HQ}_{\mathrm{derm}}\right)$ routes of exposure to the detected heavy metals. The combined HI values for adults are 0.195 and 0.166 for the soils from the interior and boundary areas of the site, respectively; both values are below the safety threshold $(\mathrm{HI}<1.0)$. Moreover, the current heavy metal concentrations in soil in the site do not pose any additional noncarcinogenic hazard for adults living in or near the site. The combined HI values for children are 1.36 and 1.16 for the soils from the interior and boundary areas of the site, respectively, indicating that the heavy metals detected would harm the children. The individual HIs for $\mathrm{Cr}$ and As are 1 to 2 orders of magnitude higher than those of the other heavy metals. As the concentration variation ranges of $\mathrm{As}$ and $\mathrm{Cr}$ change a little along the soil depth, the heavy metals detected are hazardous to children's health within the area of sampling. Therefore, children should not be permitted to go to the site because they are sensitive receptors, and protective measures should be taken.

3.4.2. Carcinogenic Risk. Carcinogenic risks of carcinogens (As, $\mathrm{Cr}, \mathrm{Pb}$, and $\mathrm{Ni}$ ) are shown in Table $8 . R_{\text {total }}$ of the soil samples from the interior and boundary areas of the site are $4.35 E-5$ and $4.48 E-5$, respectively, which are within the range of $1 E-6-1 E-4$. Comparison of the values of $R$ using multiple pathways shows that carcinogenic risks are primarily attributed to oral exposure to As. $R_{\text {total }}$ for As are 2 to 4 orders of magnitude higher than those of the other three heavy metals.

\section{Discussion}

Landfill leachates pose a direct threat to the soils in open dumpsites that do not use appropriate bottom liners and leachate collection systems. The rate and characteristics of leachate produced depend on numerous factors, such as solid waste composition, particle size, degree of compaction, site hydrology, landfill age, moisture and temperature conditions, and available oxygen [29]. Young leachate mainly in the acidogenic phase has large amounts of degradable organic substances and heavy metals. Mature leachate undergoing methanogenic phase is normally characterised by a low BOD/COD ratio and by heavy metals [30]. During landfill waste stabilization, the nonconservative components of leachate (primarily organic in nature) tend to decompose and stabilise over time, whereas conservative components remain 
TABLE 7: Noncarcinogenic hazards of heavy metals corresponding to different exposure pathways.

\begin{tabular}{|c|c|c|c|c|c|c|}
\hline & \multirow{2}{*}{ Groups } & \multirow{2}{*}{ Heavy metals } & \multicolumn{3}{|c|}{ Noncarcinogenic hazard } & \multirow{2}{*}{ HI } \\
\hline & & & $\mathrm{HQ}_{\text {ing }}$ & $\mathrm{HQ}_{\text {inh }}$ & $\mathrm{HQ}_{\text {derm }}$ & \\
\hline \multirow{16}{*}{ Soil from the interior area of the site } & \multirow{8}{*}{ Children } & As & $6.69 E-01$ & NC & $5.63 E-02$ & $7.26 E-01$ \\
\hline & & $\mathrm{Cr}$ & $3.39 E-01$ & $9.96 E-04$ & $1.95 E-02$ & $3.59 E-01$ \\
\hline & & $\mathrm{Cu}$ & $1.03 E-02$ & $2.88 E-07$ & $3.95 E-05$ & $1.03 E-02$ \\
\hline & & $\mathrm{Pb}$ & $2.39 E-01$ & $2.67 E-06$ & $7.34 E-04$ & $2.40 E-01$ \\
\hline & & $\mathrm{Ni}$ & $1.85 E-02$ & $5.05 E-07$ & $7.89 E-05$ & $1.86 E-02$ \\
\hline & & $\mathrm{Zn}$ & $6.40 E-03$ & $1.79 E-07$ & $3.68 E-05$ & $6.43 E-03$ \\
\hline & & $\mathrm{Hg}$ & $3.90 E-03$ & $3.83 E-07$ & $4.48 E-05$ & $3.94 E-03$ \\
\hline & & Sum & $1.29 E+00$ & $1.00 E-03$ & $7.67 E-02$ & $1.36 E+00$ \\
\hline & \multirow{8}{*}{ Adults } & As & $9.37 E-02$ & $\mathrm{NC}$ & $1.03 E-02$ & $1.04 E-01$ \\
\hline & & $\mathrm{Cr}$ & $4.74 E-02$ & $4.68 E-04$ & $3.56 E-03$ & $5.14 E-02$ \\
\hline & & $\mathrm{Cu}$ & $1.44 E-03$ & $1.35 E-07$ & $7.22 E-06$ & $1.45 E-03$ \\
\hline & & $\mathrm{Pb}$ & $3.35 E-02$ & $1.25 E-06$ & $1.34 E-04$ & $3.37 E-02$ \\
\hline & & $\mathrm{Ni}$ & $2.59 E-03$ & $2.37 E-07$ & $1.44 E-05$ & $2.61 E-03$ \\
\hline & & $\mathrm{Zn}$ & $8.95 E-04$ & $8.43 E-08$ & $6.72 E-06$ & $9.02 E-04$ \\
\hline & & $\mathrm{Hg}$ & $5.45 E-04$ & $1.80 E-07$ & $8.19 E-06$ & $5.54 E-04$ \\
\hline & & Sum & $1.80 E-01$ & $4.70 E-07$ & $1.40 E-02$ & $1.95 E-04$ \\
\hline \multirow{16}{*}{ Soil from boundary area of the site } & \multirow{8}{*}{ Children } & As & $6.94 E-01$ & $\mathrm{NC}$ & $5.84 E-02$ & $7.53 E-01$ \\
\hline & & $\mathrm{Cr}$ & $2.33 E-01$ & $6.85 E-04$ & $1.34 E-02$ & $2.47 E-01$ \\
\hline & & $\mathrm{Cu}$ & $6.31 E-03$ & $1.76 E-07$ & $2.42 E-05$ & $6.34 E-03$ \\
\hline & & $\mathrm{Pb}$ & $1.31 E-01$ & $1.47 E-06$ & $4.03 E-04$ & $1.32 E-01$ \\
\hline & & $\mathrm{Ni}$ & $1.75 E-02$ & $4.75 E-07$ & $7.43 E-05$ & $1.75 E-02$ \\
\hline & & $\mathrm{Zn}$ & $2.52 E-03$ & $7.06 E-08$ & $1.45 E-05$ & $2.53 E-03$ \\
\hline & & $\mathrm{Hg}$ & $3.90 E-03$ & $3.83 E-07$ & $4.48 E-05$ & $3.94 E-03$ \\
\hline & & Sum & $1.09 E+00$ & $6.87 E-04$ & $7.24 E-02$ & $1.16 E+00$ \\
\hline & \multirow{8}{*}{ Adults } & As & $9.72 E-02$ & $\mathrm{NC}$ & $1.07 E-02$ & $1.08 E-01$ \\
\hline & & $\mathrm{Cr}$ & $3.26 E-02$ & $3.22 E-04$ & $2.45 E-03$ & $3.53 E-02$ \\
\hline & & $\mathrm{Cu}$ & $8.84 E-04$ & $8.28 E-08$ & $4.42 E-06$ & $8.88 E-04$ \\
\hline & & $\mathrm{Pb}$ & $1.84 E-02$ & $6.88 E-07$ & $7.36 E-05$ & $1.85 E-02$ \\
\hline & & $\mathrm{Ni}$ & $2.44 E-03$ & $2.23 E-07$ & $1.36 E-05$ & $2.46 E-03$ \\
\hline & & $\mathrm{Zn}$ & $3.52 E-04$ & $3.32 E-08$ & $2.65 E-06$ & $3.55 E-04$ \\
\hline & & $\mathrm{Hg}$ & $5.45 E-04$ & $1.80 E-07$ & $8.19 E-06$ & $5.54 E-04$ \\
\hline & & Sum & $1.52 E-01$ & $3.23 E-07$ & $1.32 E-02$ & $1.66 E-01$ \\
\hline
\end{tabular}

NC: not calculated.

TABLE 8: Individual carcinogenic risk of carcinogens in the site.

\begin{tabular}{|c|c|c|c|c|c|}
\hline & \multirow{2}{*}{ Heavy metals } & \multicolumn{3}{|c|}{ Carcinogenic risk } & \multirow{2}{*}{$R_{\text {total }}$} \\
\hline & & $R_{\text {ing-s }}$ & $R_{\text {inh-s }}$ & $R_{\text {derm-s }}$ & \\
\hline \multirow{5}{*}{ Soil from the interior area in the site } & As & $3.91 E-05$ & $2.04 E-09$ & $3.66 E-06$ & $4.28 E-05$ \\
\hline & $\mathrm{Cr}$ & NC & $2.87 E-07$ & $\mathrm{NC}$ & $2.87 E-07$ \\
\hline & $\mathrm{Pb}$ & $3.70 E-07$ & NC & $\mathrm{NC}$ & $3.70 E-07$ \\
\hline & $\mathrm{Ni}$ & $\mathrm{NC}$ & $1.89 E-09$ & $\mathrm{NC}$ & $1.89 E-09$ \\
\hline & Sum & $3.95 E-05$ & $2.91 E-07$ & $3.66 E-06$ & $4.35 E-05$ \\
\hline \multirow{5}{*}{ Soil from the boundary area of the site } & As & $4.06 E-05$ & $2.12 E-09$ & $3.79 E-06$ & $4.44 E-05$ \\
\hline & $\mathrm{Cr}$ & $\mathrm{NC}$ & $1.97 E-07$ & $\mathrm{NC}$ & $1.97 E-07$ \\
\hline & $\mathrm{Pb}$ & $2.03 E-07$ & $\mathrm{NC}$ & $\mathrm{NC}$ & $2.03 E-07$ \\
\hline & $\mathrm{Ni}$ & $\mathrm{NC}$ & $1.04 E-09$ & $\mathrm{NC}$ & $1.04 E-09$ \\
\hline & Sum & $4.08 E-05$ & $2.00 E-07$ & $3.79 E-06$ & $4.48 E-05$ \\
\hline
\end{tabular}

NC: not calculated. 
after waste stabilization has occurred. Conservative components include various heavy metals, chloride and sulphide $[31,32]$. Analysis of soil contamination characteristics of the dumpsite showed that, after 11 years of operation, the landfill leachates are in a mature stage with mainly conservative components remaining at the time of this writing.

This study screened 17 soil samples from the open dumpsite for 210 parameters and compounds. Nine inorganic pollutants and heavy metals were identified in 15 of the samples and 11 VOCs/SVOCs in 17 categories (for a total of 195 VOCs/SVOCs detected). The presence of heavy metals and organic compounds in the soil samples indicates that significant contamination of the soil was caused by leachate migration in the open dumping site. Heavy metals detected were more hazardous than the other compounds in the soil because, except for the conservative components, most species of organic contaminants obtained from the leachate are biodegradable over time. This phenomenon reflects the contamination status of similar contaminated sites in China.

The risk assessment of open dumping sites in the suburbs, which offers guidance for choosing a future land use pattern or an appropriate redevelopment option, has received limited attention in China. Different reference systems are used to conduct potential ecological risk assessment with varying results. Using the environmental background values of Shandong and the secondary standard of GB15618-1995 as screening levels, considerable differences exist in $E_{r}^{i}$ for $\mathrm{Hg}$, which can directly affect the combined ecological risks of the soil samples. As an appropriate reference system is very important in the procedure of ecological risk assessment, the secondary standard of GB15618-1995, which takes soil ecology and soil quality into consideration, is a priority as screening levels.

The results of the health risk assessment show that, given the high toxicity of As and $\mathrm{Cr}$, these elements have become major sources of risks even though their concentrations in the soil are not excessive. Both carcinogenic risk and noncarcinogenic hazards posed by heavy metals to adults are acceptable, whereas noncarcinogenic hazards to children exceed the safety threshold, which negatively affects the target community. Integrated health risk assessment should include the assessment of pollutants carried by four media (atmosphere, soil, water, and food chain) using the three main pathways (ingestion, inhalation, and dermal absorption) to the body. In view of the lack of information on the eating habits of the local population and the limitation on testing programmes, this study only evaluated the health risks of heavy metals in soil through three exposure pathways: oral ingestion, inhalation, and dermal absorption. The other toxic substances (e.g., VOCs/SVOCs detected) and exposure pathways (e.g., food intake) are not included. Moreover, the assessment results based on the total metal concentrations may overestimate the actual risks. A realistic assessment of the actual health risks associated with heavy metals in soils requires an evaluation of bioaccessible metal fractions [21]. The combined health risks of various heavy metals are obtained using a simple addition of individual heavy metal risk. The method may not accurately characterise the combined effects of heavy metals on different receptors because of different hazard mechanisms of various substances on the human body. Future studies on the relational model of the available form and content of pollutants detected and risk assessment should be promoted in China.

\section{Conclusions}

The concentrations of pollutants (15 inorganic pollutants and heavy metals and 195 VOCs/SVOCs) in soil samples from an abandoned open dumpsite in the suburbs in Heze, Shandong, China, were investigated. The results show that the mean concentration levels obtained for pollutants in the soils from the interior area were relatively higher than those from the boundary area. Inorganic pollutants and heavy metals were detected in all the soil samples, whereas VOCs/SVOCs were detected only in the topsoil of the site with limited effect on a depth of less than $2 \mathrm{~m}$. All of the concentrations of VOCs/SVOCs were below the corresponding screening levels, whereas a number of heavy metals ( $\mathrm{As}, \mathrm{Ni}$, and $\mathrm{Zn}$ ) exceeded these levels.

The potential ecological risk assessment indicated that heavy metals in most of the soil samples posed low ecological risk to the ecosystem, except for the samples from the site with a high accumulation level of $\mathrm{Hg}$, which posed a considerably high risk based on the environmental background values of Shandong. The ecological risk of individual heavy metals in the soils from the interior area of the site was higher than that from the boundary area. Human health risks were assessed based on environmental exposure to heavy metals. Both carcinogenic risk and noncarcinogenic hazards of heavy metals for adults in soil samples were acceptable, whereas the noncarcinogenic hazards to children exceeded the safety threshold. Health risks are primarily attributed to oral exposure to As and Cr.

\section{Conflict of Interests}

The authors declare that there is no conflict of interests regarding the publication of this paper.

\section{Acknowledgments}

The authors would like to thank those who work in the abandoned open dumpsite for giving them permission to collect samples. They are also grateful to Dongliang Liu and Zhenzhen Zhang, the field engineers in BCEG Environmental Remediation Co., Ltd., for allowing them to collect the soil samples and for participating in the discussion.

\section{References}

[1] S. S. Nas and A. Bayram, "Municipal solid waste characteristics and management in Gümüşhane, Turkey," Waste Management, vol. 28, no. 12, pp. 2435-2442, 2008.

[2] A. Eguchi, T. Isobe, K. Ramu et al., "Soil contamination by brominated flame retardants in open waste dumping sites in Asian developing countries," Chemosphere, vol. 90, no. 9, pp. 2365-2371, 2013. 
[3] China Center of DPP, "190 million tons of MSW generated from rural life with little properly treated," NetEase Publishing PhysicsWeb, 2014, http://money.163.com/13/0228/ 18/8OQOGSB600254T7L.html.

[4] H. Deng, J. Zhang, Z. Chen, and D. Wand, "Pollution and assessment of heavy metals in the tidal flat sediment near Laogang Garbage Landfill of Shanghai," Chinese Journal of Soil Science, vol. 38, no. 2, pp. 347-351, 2007.

[5] National Bureau of Statistics of China, Statistical Yearbook of China, China Statistics Press, Beijing, China, 2009.

[6] P. Zhang and Z.-C. Wu, "Municipal sludge as landfill barrier material," Journal of Environmental Sciences, vol. 17, no. 3, pp. 474-477, 2005.

[7] L. Bengtsson, D. Bendz, W. Hogland, H. Rosqvist, and M. Akesson, "Water balance for landfills of different age," Journal of Hydrology, vol. 158, no. 3-4, pp. 203-217, 1994.

[8] O. J. Johansen and D. A. Carlson, "Characterization of sanitary landfill leachates," Water Research, vol. 10, no. 12, pp. 1129-1134, 1976.

[9] J. Wiszniowski, D. Robert, J. Surmacz-Gorska, K. Miksch, and J. V. Weber, "Landfill leachate treatment methods: a review," Environmental Chemistry Letters, vol. 4, no. 1, pp. 51-61, 2006.

[10] H.-B. Lee and T. E. Peart, "Determination of 4-nonylphenol in effluent and sludge from sewage treatment plants," Analytical Chemistry, vol. 67, no. 13, pp. 1976-1980, 1995.

[11] K.-J. Hong, S. Tokunaga, and T. Kajiuchi, "Evaluation of remediation process with plant-derived biosurfactant for recovery of heavy metals from contaminated soils," Chemosphere, vol. 49, no. 4, pp. 379-387, 2002.

[12] S. Kanmani and R. Gandhimathi, "Assessment of heavy metal contamination in soil due to leachate migration from an open dumping site," Applied Water Science, vol. 3, no. 1, pp. 193-205, 2013.

[13] S. M. Ali, A. Pervaiz, B. Afzal, N. Hamid, and A. Yasmin, "Open dumping of municipal solid waste and its hazardous impacts on soil and vegetation diversity at waste dumping sites of Islamabad city," Journal of King Saud University-Science, vol. 26, no. 1, pp. 59-65, 2014.

[14] G. Yidong, G. Chuan, L. Zhendong, N. Xinjun, Z. Zhiyuan, and L. Ancheng, "Metal contents and composting feasibility of rural waste from Abandoned Dumping Site in Zhejiang, China," Energy Procedia, vol. 5, pp. 1274-1278, 2011.

[15] L. Hakanson, "An ecological risk index for aquatic pollution control. A sedimentological approach," Water Research, vol. 14, no. 8, pp. 975-1001, 1980.

[16] Q. Tang, G. Liu, C. Zhou, H. Zhang, and R. Sun, "Distribution of environmentally sensitive elements in residential soils near a coal-fired power plant: potential risks to ecology and children's health," Chemosphere, vol. 93, no. 10, pp. 2473-2479, 2013.

[17] B. Chen, H. Y. Qiu, Y. N. Guo, L. Y. Wang, and X. Wang, "Heavy metal contamination and health risk assessment in the zinc mine set area of Youxi, China," Journal of Xiamen University (Natural Science), vol. 51, no. 2, pp. 245-251, 2012.

[18] US EPA, Risk Assessment Guidance for Superfund, Vol. I: Human Health Evaluation Manual, Office of Emergency and Remedial Response, Washington, DC, USA, 1989.

[19] US EPA, Supplemental Guidance for Developing Soil Screening Levels for Superfund Sites, Office of Emergency and Remedial Response, Washington, DC, USA, 2002.
[20] E. de Miguel, I. Iribarren, E. Chacón, A. Ordoñez, and S. Charlesworth, "Risk-based evaluation of the exposure of children to trace elements in playgrounds in Madrid (Spain)," Chemosphere, vol. 66, no. 3, pp. 505-513, 2007.

[21] X.-S. Luo, J. Ding, B. Xu, Y.-J. Wang, H.-B. Li, and S. Yu, "Incorporating bioaccessibility into human health risk assessments of heavy metals in urban park soils," Science of the Total Environment, vol. 424, pp. 88-96, 2012.

[22] Y. B. Man, X. L. Sun, Y. G. Zhao et al., "Health risk assessment of abandoned agricultural soils based on heavy metal contents in Hong Kong, the world's most populated city," Environment International, vol. 36, no. 6, pp. 570-576, 2010.

[23] M. Fryer, C. D. Collins, H. Ferrier, R. N. Colvile, and M. J. Nieuwenhuijsen, "Human exposure modelling for chemical risk assessment: a review of current approaches and research and policy implications," Environmental Science and Policy, vol. 9, no. 3, pp. 261-274, 2006.

[24] M. S. Lu, E. J. Wu, and M. J. Li, "Study on the hydrogeochemistry genesis of high fluorine shallow-bed groundwater in Southwestern Shandong Province," Coal Geology \& Exploration, vol. 21, no. 5, pp. 39-42, 2001.

[25] E. Wcisło, D. Ioven, R. Kucharski, and J. Szdzuj, "Human health risk assessment case study: an abandoned metal smelter site in Poland," Chemosphere, vol. 47, no. 5, pp. 507-515, 2002.

[26] H.-Z. Zhang, Y.-M. Luo, J.-Q. Xia, and H.-B. Zhang, "Some thoughts of the comparison of risk based soil environmental standards between different countries," Journal of Environmental Sciences, vol. 32, no. 3, pp. 795-802, 2011.

[27] H. Liu, S. Sang, and L. Cao, "Study on geochemistry of heavy metals in municipal landfill leachate," Studies of Trace Elements and Health, vol. 24, no. 2, pp. 58-61, 2007.

[28] I. Gržetić and R. H. Ahmed Ghariani, "Potential health risk assessment for soil heavy metal contamination in the central zone of Belgrade (Serbia)," Journal of the Serbian Chemical Society, vol. 73, no. 8-9, pp. 923-934, 2008.

[29] M. A. Ashraf, I. Yusoff, M. Yusof, and Y. Alias, "Study of contaminant transport at an open-tipping waste disposal site," Environmental Science and Pollution Research, vol. 20, no. 7, pp. 4689-4710, 2013.

[30] N. Yusof, A. Haraguchi, M. A. Hassan, M. R. Othman, M. Wakisaka, and Y. Shirai, "Measuring organic carbon, nutrients and heavy metals in rivers receiving leachate from controlled and uncontrolled municipal solid waste (MSW) landfills," Waste Management, vol. 29, no. 10, pp. 2666-2680, 2009.

[31] S. Dudka, M. Piotrowska, A. Chlopecka, and T. Witek, "Trace metal contamination of soils and crop plants by the mining and smelting industry in Upper Silesia, South Poland," Journal of Geochemical Exploration, vol. 52, no. 1-2, pp. 237-250, 1995.

[32] T. Fletcher, "Neighborhood change at Love Canal: contamination, evacuation and resettlement," Land Use Policy, vol. 19, no. 4, pp. 311-323, 2002.

[33] L. Ferreira-Baptista and E. de Miguel, "Geochemistry and risk assessment of street dust in Luanda, Angola: a tropical urban environment," Atmospheric Environment, vol. 39, no. 25, pp. 4501-4512, 2005.

[34] R.-Z. Li, C.-R. Pan, J. Chen, Y.-M. Jiang, and G.-Z. Ding, "Heavy metal contamination and health risk assessment for urban topsoil and dust in Tongling City," China Environmental Science, vol. 32, no. 12, pp. 2261-2270, 2012. 

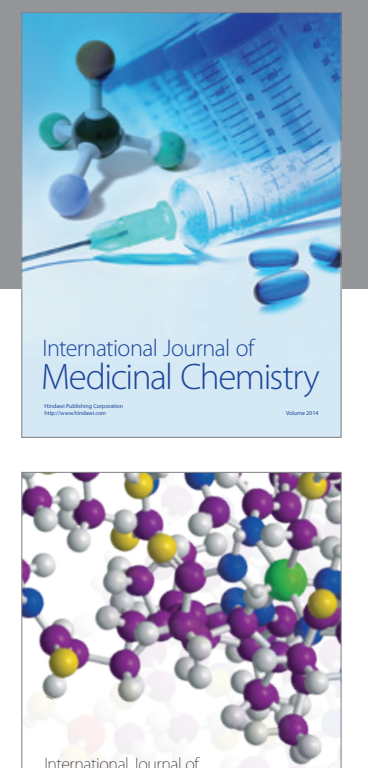

\section{Carbohydrate} Chemistry

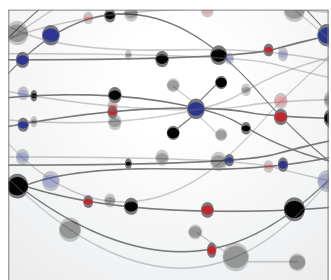

The Scientific World Journal
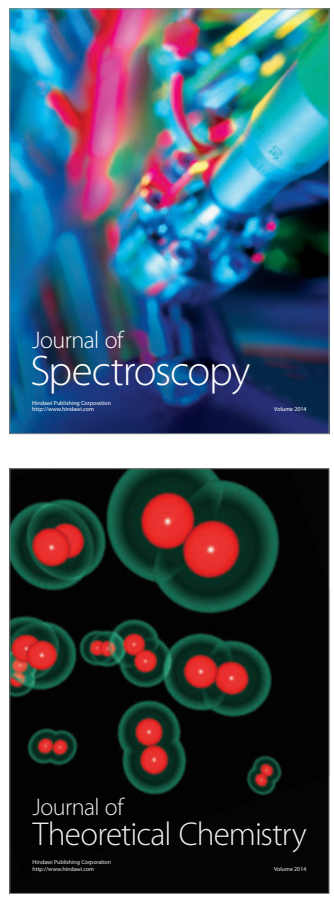
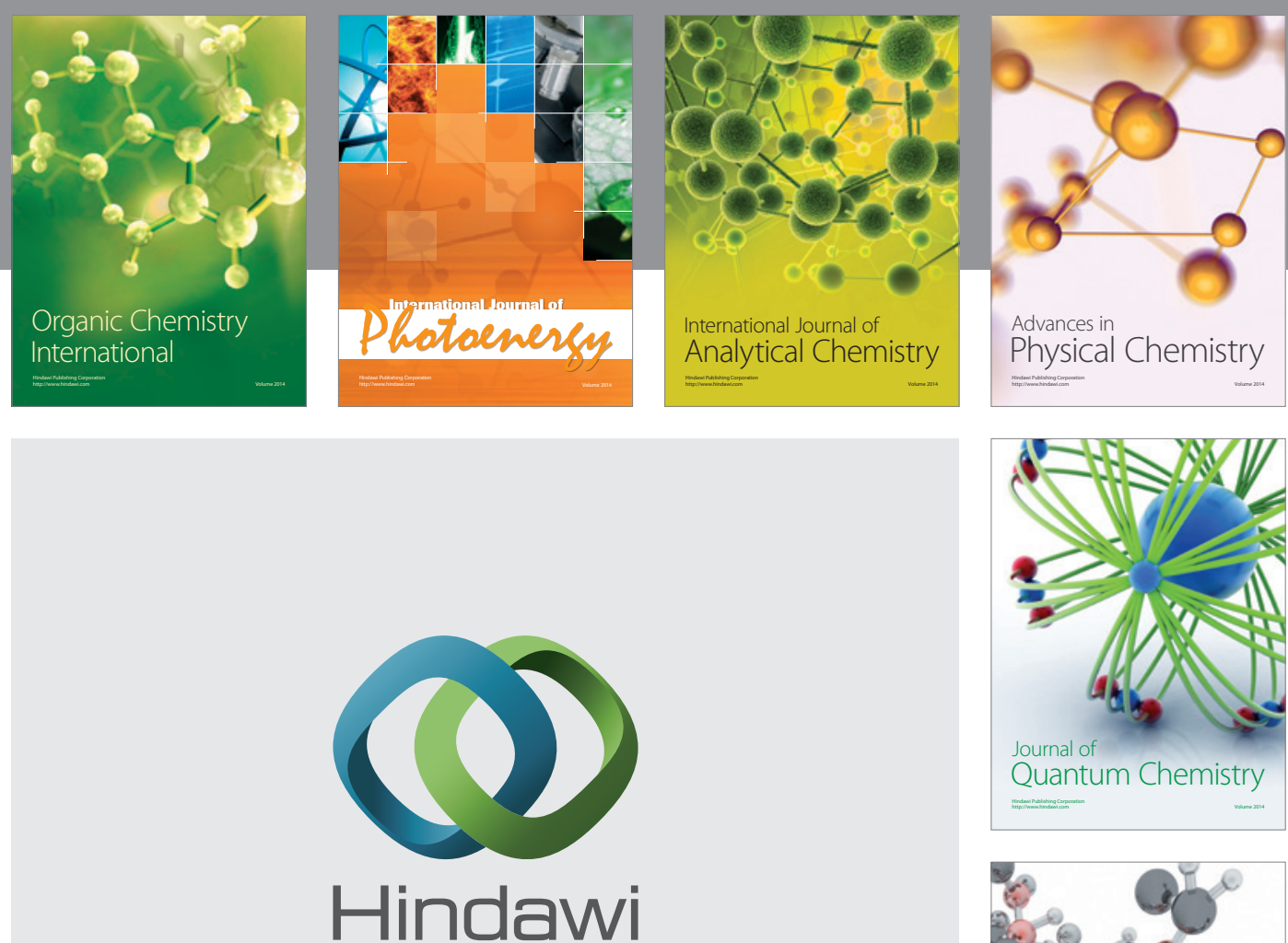

Submit your manuscripts at

http://www.hindawi.com

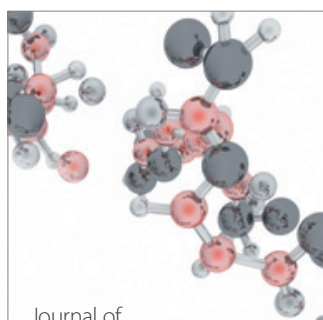

Analytical Methods

in Chemistry

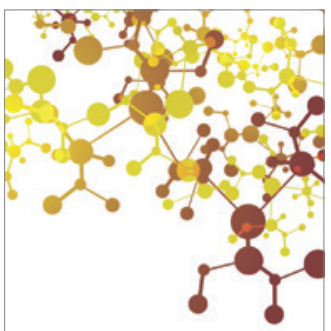

Journal of

Applied Chemistry

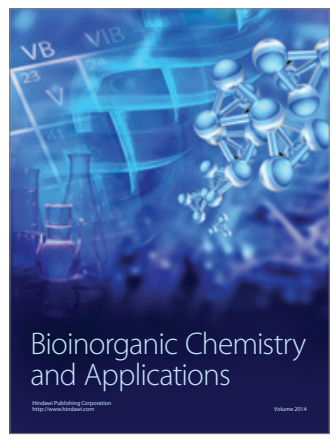

Inorganic Chemistry
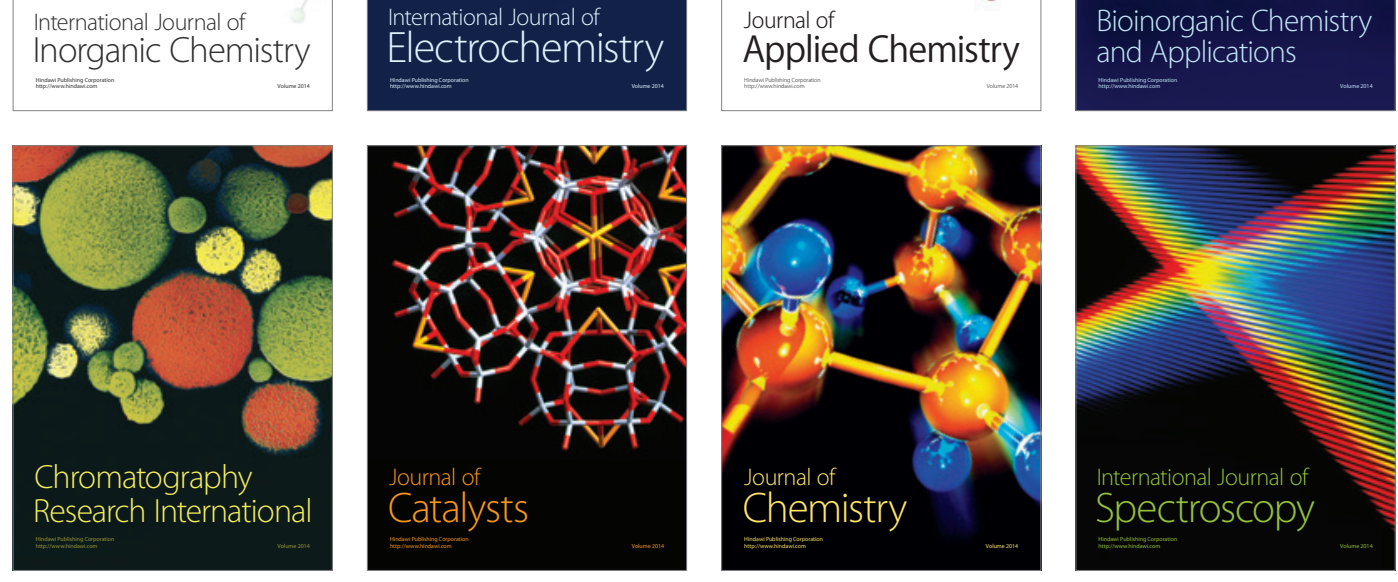